\title{
Effect of Retained Placenta And Clinical Mastitis On Reproduction Parameters, Immune Response And Steroidogenic Receptors Gene Expression In Postpartum Crossbred Crossbreed Dairy Cows
}

\section{Oglênia Ramos}

UFU: Universidade Federal de Uberlandia

\section{Amanda Rezende}

UFU: Universidade Federal de Uberlandia

\section{Paula Alvarenga}

UNIPAC: Universidade Presidente Antonio Carlos

\section{Carla Campos}

Una University Centre: Centro Universitario Una

\section{Estevão Rezende}

Faculdade de Patos de Minas

\section{Marcelo Silva}

UFU: Universidade Federal de Uberlandia

Luisa Cunha Carneiro ( $\square$ luisacunhacarneiro@hotmail.com )

Universidade de Sao Paulo https://orcid.org/0000-0002-5324-010X

\section{Giovanna Moraes}

UFU: Universidade Federal de Uberlandia

João Paulo Saut

UFU: Universidade Federal de Uberlandia

\section{Ricarda Santos}

UFU: Universidade Federal de Uberlandia

\section{Research Article}

Keywords: disease, inflammation, puerperium, transcription

Posted Date: September 17th, 2021

DOl: https://doi.org/10.21203/rs.3.rs-832847/v1

License: (9) This work is licensed under a Creative Commons Attribution 4.0 International License. 
Page $2 / 21$ 


\section{Abstract}

The purpose of this study was to evaluate the effect of retained placenta (RP) and clinical mastitis (CM) on the reproductive efficiency of crossbred dairy cows during the postpartum period and to investigate the effect of them in some innate immune system indicators. For this, in the first experiment a total of 232 crossbred dairy cows were evaluated and divided into three groups as: healthy control, RP and CM. The incidence of RP and CM was evaluated after parturition until 30 days postpartum (DPP) and reproductive rates were measured. In experiment 2, 30 crossbred dairy cows were divided into three groups as in Experiment 1. Between 40 and 50 DPP, clinical, gynecological examination and endometrial cytobrush were performed to evaluate subclinical endometritis and gene expression of interleukin- $1 \beta$ (IL$1 \beta)$, interleukin-6 (IL-6), chemokine ligand -5 (CCL5), estrogen a (ESR1) and progesterone (PGR) receptors by qRT-PCR analysis. In Experiment 1, the conception rate at $1^{\text {st }} \mathrm{Al}$ was lower in RP and $\mathrm{CM}$ groups and pregnancy rate at 150 days decreased in cows with $\mathrm{CM}$. Calving-to- $1^{\text {st }} \mathrm{Al}$ interval and days open were shorter in healthy cows. In Experiment 2 the occurrence of subclinical endometritis was $26.7 \%$ and was higher in cows with RP and CM. The expression of IL-1 $\beta$ was increased in RP and CM groups, while IL- 6 was less expressed in RP group. The chemokine CCL5, ESR1 and PGR were similar between groups. In conclusion, cows with RP and CM had their reproductive efficiency negatively affected and had they initial pro-inflammatory response improved by the increase of IL- $\beta$, while, IL- 6 was lower in animals with RP probably because it was evaluated later in the postpartum.

\section{Introduction}

Uterine and non-uterine diseases have a major impact on reproductive cattle, resulting in subfertility and infertility (Ribeiro et al., 2013; Sheldon and Owens, 2017). Uterine disease as retained placenta (RP), increases the first service interval and decreases conception rate (Fourichon et al. ,2000). Still, Buso et al. (2018) observed that cows with RP had 46 extra days open, $19.4 \%$ culling rate and the number of artificial insemination (Al) was significantly higher when compared to healthy cows. A relevant impact of RP is the decrease in the milk production (Dubuc et al., 2011), resulting in 355 liters less in the first 60 days of lactation (Sheldon et al., 2004).

Non-uterine diseases are also associated with reproduction failures. Clinical mastitis (CM), for example, up to 28 days postpartum (DPP) delays the normal ovary cyclicity and estrus (Huszenicza et al., 2005), reduces ovarian follicle growth rate (Lavon et al., 2011), increases the number of $\mathrm{Al}$, decreases the chances of pregnancy in the first Al and increases the days open (Campos et al., 2020; Dalanezi et al., 2020).

The negative effects of inflammatory diseases as RP and CM on reproductive efficiency are multifactorial and need further clarification (Bromfield et al., 2015; Ribeiro et al., 2016; Sheldon et al., 2019). According to Bromfield et al. (2015) and Karsch et al. (2002), the presence of the pathogens and the activation of the immune response cause changes in the pathways necessary for a normal reproduction function and generate a negative impact on fertility. Moreover, these diseases altered the expression of genes related to 
immunity and inflammation in the isthmus, ampoule and granulosa cells for up to three months after the diseases were recovered (Horlock et al., 2020).

As part of the immune response some important pro- and anti-inflammatory mediators can regulate acute and/or chronic inflammation, as they can activate neutrophils and macrophages and may increase the endothelial expression of cell adhesion molecules (Collins et al., 1995; Koh et al., 2007). These include vasoactive amines, arachidonic acid metabolites and, mainly, cytokines, which, facilitate the direction of leukocytes to inflammatory areas produced in response to infection (Huber et al., 1991).

In this study we hypothesized that diseases such as RP and CM interfere in reproduction performance, consequently alters the innate endometrial immune response and the expression of steroidogenic hormone receptors at the end of the puerperium. Based on that, we aimed first to evaluate the effects of

$\mathrm{RP}$ and $\mathrm{CM}$ on the reproductive efficiency of crossbred dairy cows (Experiment 1); and second, to evaluate the effect of these diseases on the expression of innate immune mediators as interleukin- $1 \beta(L-1 \beta)$, interleukin - 6 (IL-6), chemokine ligand 5 (CCL5), and on steroidogenic hormones receptors as estrogen receptor a (ESR1) and progesterone receptor (PGR) (Experiment 2).

\section{Material And Methods}

\subsection{Experiment 1}

\subsubsection{Herd management and reproductive activities}

In this experiment, a total of 232 cows with genetic composition $3 / 4$ Holstein $\times 1 / 4$ Gir, from two farms were used. The animals were on the third lactation and with a body condition score (BCS) between 3 and 3.5 (Edmonson et al., 1989). The first farm had 90 lactating cows with a total of $2400 \mathrm{~L} /$ day $(27$ $\mathrm{kg} / \mathrm{cow} /$ day). The second farm had 215 lactating animals with $8000 \mathrm{~L} /$ day $(37 \mathrm{~kg} / \mathrm{cow} /$ day). On both farms, cows were milked three times a day and had a sprinkler and ventilation system in the milking waiting barn. Drying therapy was performed 60 days before the expected date of calving and those dry cows were kept in a separate compost barn with a specific diet.

Three experimental groups were designed as follows: Group 1 (healthy control): cows without any puerperal disease; Group 2 (retained placenta - RP): cows that did not release fetal membranes until $12 \mathrm{~h}$ after calving (Ferreira Ademir de Moraes, 2010); Group 3 (clinical mastitis - CM): cows that presented Grade $1 \mathrm{CM}$ according to the definition proposed by Roberson (2012) until the end of the voluntary waiting period (30 DPP). Cows diagnosed with mastitis after this period were not included in the study.

A vaccination calendar was followed regularly and reproductive vaccines against bovine herpes virus 1 (BoHV-1), bovine viral diarrhea virus (BVDV) and leptospirosis, in addition to rabies and clostridiosis were performed. Cows were treated with bovine recombinant somatotropin (bST) from 60 DPP with an interval of 14 days between applications until reaching 190 days of pregnancy. 
For the reproductive management, cows were subjected to the following timed artificial insemination (TAl) protocol: - day 0: insertion of an intravaginal device containing $1.9 \mathrm{~g}$ of progesterone (P4) (CIDR®, Zoetis), application of $2.0 \mathrm{mg}$ of estradiol benzoate i.m. (Sincrodiol®, Ouro Fino), and $0.01 \mathrm{mg}$ of GnRH analog i.m. (Sincroforte ${ }^{\circledR}$, Ouro Fino); day 7: application of $25 \mathrm{mg}$ of dinoprost tromethamine i.m. (Lutalyse ${ }^{\circledR}$, Zoetis); day 9: intravaginal device withdrawal, $25 \mathrm{mg}$ of dinoprost tromethamine i.m. (Lutalyse ${ }^{\circledR}$, Zoetis) and $1.2 \mathrm{mg}$ of estradiol cypionate, i.m. (ECP®, Zoetis); day 11: timed Al for all treated animals.

Reproductive evaluations were made weekly. An ultrasound device equipped with a 7.5-MHz linear rectal transducer (Mindray® model DP-2200 VET) was used. Pregnancy diagnosis was performed $32 \pm 4$ days after Al. Reproduction performance was evaluated by: conception rate at 1st Al; pregnancy rate at 150 DPP, calving-to-1 st Al interval and days open.

\subsection{Experiment 2}

\subsubsection{Herd management}

In experiment 2, 30 crossbred $3 / 4$ Holstein $\times 1 / 4$ Gir dairy cows from three commercial dairy farms were used. Division into groups and inclusion criteria were similar to Experiment 1 as Group 1: healthy control; $(n=10)$; Group 2: cows with RP were selected (RP-group; $n=10)$ and Group 3: cows with CM during the postpartum were selected (CM group; $n=10)$. Only animals in the third lactation and with a BCS between 3 and 3.5 (Edmonson et al., 1989) were included.

The animals received supplementation based on corn silage in addition to a concentrate. Water and mineral salt were available ad libitum. Farm 1 had 280 lactating cows (7500 L/day of milk production; 27 $\mathrm{kg} /$ cow/day), Farm 2 had 270 lactating ( 6000 L/day of milk production; $22 \mathrm{~kg} / \mathrm{cow} /$ day) and Farm 3 had 195 lactating cows (4200 L/day of milk production; $22 \mathrm{~kg} / \mathrm{cow} /$ day). In all farms, the cows were milked twice a day. Drying therapy was performed 60 days before the expected date of calving, and the dry cows received a specific diet.

A vaccination calendar was followed regularly complying with all the State law for dairy herd. Cows were treated with bovine recombinant somatotropin (bST) from 60 DPP with an interval of 14 days between applications until 190 days of pregnancy.

\subsubsection{Clinical and gynecological examination}

Between 40 and 50 DPP, clinical and gynecological examinations were performed. Cows were examined clinically for general health and vital parameters according to Feitosa (2008). The specific examination of the genital tract was performed by rectal palpation and an ultrasound evaluation of the uterine horns to check the uterus and intrauterine fluid was performed; in addition, the characteristics of vaginal discharge was assessed by Metricheck ${ }^{\circledR}$ device (McDougall et al., 2007; Sheldon et al., 2019).

\subsubsection{Endometrial samples}


After general examination, two endometrial cell samples were collected between 40 and 50 DPP using the cytobrush technique (Kasimanickam et al., 2004). The first sample was used to perform qRT-PCR. After collection, the cytobrush was stored in a sterile cryogenic tube with a screw cap free of DNAse, RNAse and heavy metals. After samples were collected, they were transferred in a liquid nitrogen bottle $(1 \mathrm{~L})$ and subsequently stored in a vertical ultra-freezer at $-80^{\circ} \mathrm{C}$.

The second cytobrush sample was used for endometrial cytological slides for subclinical endometritis diagnosis. The slides were stained using the Rapid Panotic kit (Laborclin ${ }^{\circledR}$, Pinhais, Brazil), according to the manufacturer's recommendations. Readings were made under an optical microscope at $40 \mathrm{X}$ magnification. A total of 100 cells were counted and the percentages of polymorphonuclear (PMN) cells and epithelial cells recorded. Subclinical endometritis was considered when the percentage of PMN cells (neutrophils) was $\geq 5 \%$ (Gilbert et al., 2005) compared to epithelial cells.

\subsubsection{Real-time polymerase chain reaction (qRT-PCR)}

The RNA extraction from the first endometrial cytobrush sample was performed using a Maxwell® 16 Instrument (Promega, Madison, WI, USA) with the extraction kit Maxwell@ 16 LEV simply RNA Tissue Kit (AS1280, Promega, Madison, WI, USA). All steps were followed the manufacturer's recommendation. A total of $200 \mu \mathrm{L}$ of homogenization solution were added to each cryogenic tube containing a cytobrush, then vortexed to recover the cytobrush endometrial secretion. After that, lysis buffer $(200 \mu \mathrm{L})$ was added and tubes were vortexed again. The supernatants were collected and placed in the cartridges (disposable rack available in the kit). The cartridges were prepared using all reagents and subsequently inserted into the Maxwell $\circledast 16$ Instrument for RNA extraction, after which the total RNA was quantified on a Quantus ${ }^{\text {TM }}$ Fluorometer using the QuantiFluor ${ }^{\circledR}$ RNA System kit (E3310, Promega, Madison, WI, USA) according to the manufacturer's recommendations.

Reverse transcription (RT) was performed using the GoScript ${ }^{\text {TM }}$ Reverse Transcription System kit (A5001, Promega, Madison, WI, USA). All steps were performed according to the manufacturer's recommendations. Initially, $5 \mu \mathrm{L}$ of Mix qDNA removal were previously prepared with $10 \mu \mathrm{L}$ of the respective sample and this mixture placed in the thermocycler for the first incubation. Meanwhile, RT Mix was prepared to be mixed in the sample tubes and incubated in a thermocycler again for RT enzyme denaturation. Finally, the cDNA of each sample was quantified on a Quantus ${ }^{\mathrm{TM}}$ Fluorometer using the QuantiFluor ${ }^{\text {TM }}$ ssDNA System kit (E3190, Promega, Madison, WI, USA), and stored in a freezer at $-20^{\circ} \mathrm{C}$.

Quantification of genes that encode the pro-inflammatory mediators such L-1 $\beta$, IL-6, CCL5, and ESR1 and PGR receptors were performed with an Applied Biosystems 7300 Real-Time PCR System (Applied Biosystems, Foster, CA, USA), using the threshold cycle (Ct) comparative method. The Glyceraldehyde-3Phosphate Dehydrogenase (GAPDH) gene was used as a control. An Axygen ${ }^{\circledR}$ PCR-96 AB-C 96-well plate (Axygen 214 Scientific, Union City, CA, USA) was used and the amplifications were performed in duplicate. The reaction conditions were determined previously by standardized cycles of $50^{\circ} \mathrm{C}$ for $2 \mathrm{~min}, 95^{\circ} \mathrm{C}$ for 2 min, 40 cycles of $95^{\circ} \mathrm{C}$ for $15 \mathrm{~s}$ and $60^{\circ} \mathrm{C}$ for $1 \mathrm{~min}$. 
For the reaction, a Quantinova ${ }^{\mathrm{TM}}$ Sybr ${ }^{\circledR}$ Green PCR kit was used. The proportions of the reagents used in the mix for each sample were: $5 \mu \mathrm{L}$ of sybr green PCR Master MIX, 1.0 $\mu \mathrm{L}$ of QN ROX Reference Dye, 0.2 $\mu \mathrm{L}$ of forward primer, $0.2 \mu \mathrm{L}$ of reverse primer, $1.6 \mu \mathrm{L}$ of RNAse-free water and $2.0 \mu \mathrm{L}$ of cDNA at a concentration of $35 \mathrm{ng} / \mu \mathrm{L}$. The primers used to amplify IL-1 $\beta, \mathrm{IL}-6, \mathrm{CCL} 5, \mathrm{ESR} 1$ and PGR were shown in Table 1. The endogenous gene selected was GAPDH, as it is expressed in uterine tissue (Wathes et al., 2009).

Table 1 - Primer sequence for mRNA amplification by real-time polymerase chain reaction (qRT-PCR)

\begin{tabular}{lll} 
Gene & Primer direction & Primer sequence \\
\hline IL1 $\beta$ & Forward & ACGAGTTTCTGTGTGACGCA \\
\cline { 2 - 3 } & Reverse & TGCAGAACACCACTTCTCGG \\
\hline IL6 & Forward & GGGCTCCCATGATTGTGGTA \\
\cline { 2 - 3 } & Reverse & GTGTGCCCAGTGGACAGGTT \\
\hline CCL5 & Forward & CATGGCAGCAGTTGTCTTTATCA \\
\cline { 2 - 3 } & Reverse & CTCTCGCACCCACTTCTTCTCT \\
\hline ESR1 & Forward & CAGGCACATGAGCAACAAAG \\
\cline { 2 - 3 } & Reverse & TCCAGCAGCAGGTCGTAGAG \\
\hline PGR & Forward & TCCCCCCACTGATCAACTTG \\
\cline { 2 - 3 } & Reverse & TCCGAAAACCTGGCAGTGA \\
\hline GAPDH & Forward & GGTCACCAGGGCTGCTTTTA \\
\cline { 2 - 3 } & Reverse & TTCCCGTTCTCTGCCTTGAC
\end{tabular}

Note: IL-1 $\beta$ - Interleukin 1 $\beta$; IL-6 - Interleukin 6; CCL5 - Chemokine 5; ESR1 - a estrogen receptor; PGR Progesterone receptor; GAPDH - Glyceraldehyde-3-phosphate dehydrogenase.

\subsubsection{Statistical analysis}

All data were recorded in a Microsoft Excel spreadsheet (Microsoft Corp., Redmond, WA) before statistical analysis. Statistical analyses were performed using SAS Studio (SAS Institute Inc., Cary, NC). Cows were considered as an experimental unit.

Distributions and normality tests were performed using the Univariate procedure. Normality was visually assessed via the Kolmogorov Smirnov method. The number of calving-1st Al interval and number of days open were utilized as a dependent variable and assessed with ANOVA using a generalized linear mixed model, fitted using the GLIMMIX procedure of SAS with a Gaussian distribution and an identity link function, with farm as the random effect and groups (healthy vs. RP vs. CM) as an independent variable. 
A generalized linear mixed model with the GLIMMIX procedure was used to assess the conception rate at calving-1 st Al interval and pregnancy rate at 150 days postpartum as binary dependent variables, using logistic regression with farm as the random effect and groups (healthy vs. RP vs. CM) as an independent variable. Only variables with a P-value of $\leq 0.15$ were retained in the final model. Additionally, the effects of $\mathrm{CM}$ and RP on calving to calving-1st Al interval and days open were analyzed using univariate models assessed by log-rank tests with PROC LIFETEST, where survival analyses curves were made.

For quantitative variables Kolmogorov-Smirnov test was selected to verify whether or not the data presented parametric distribution. The variables with parametric distribution were subjected to analysis of variance (parametric ANOVA) and Bonferroni's Multiple Comparison post-test. Variables with nonparametric distribution were analyzed using the Kruskal-Wallis test (non-parametric ANOVA) and Dunn's Multiple Comparison post-test. Statistical significance was defined as $P \leq 0.05$ for the main effects and interactions.

\section{Results}

\subsection{Effect of retained placenta and clinical mastitis on reproductive parameters}

In Experiment 1, a total of 232 cows were evaluated, from this, a total of $79.3 \%$ remained healthy, while $9.5 \%$ had RP and $11.2 \%$ were diagnosed with $\mathrm{CM}$.

Animals with RP and CM had the calving-1 st Al interval longer compared to healthy control cows (63.7 \pm 3.3 days; $63.5 \pm 3.7$ days and $53.1 \pm 1.5$ days, respectively, $P=0.00130 .0001 ;$ Table 2$)$. The days open were shorter for healthy cows $(90.1 \pm 6.7 ; \mathrm{P}<0.0040$; Table 2$)$ when compared to other groups.

Table 2 - Effect of retained placenta and clinical mastitis postpartum on calving to $1^{\text {st }}$ artificial insemination interval, days open, conception rate at $1^{\text {st }}$ artificial insemination and pregnancy rate at 150 days postpartum in crossbreed dairy cows.

\begin{tabular}{|llllll|}
\hline Groups & $\mathbf{n}$ & $\begin{array}{l}\text { Calving to } 1^{\text {st }} \\
\text { Al (mean } \pm \text { SE) }\end{array}$ & $\begin{array}{l}\text { DO } \\
(\text { mean } \pm \text { SE) }\end{array}$ & $\begin{array}{l}\text { Conception rate } \\
\text { at 1 }\end{array}$ & $\begin{array}{l}\text { Pregnancy } \text { Al (\%) } \\
150 \text { DPP }\end{array}$ \\
\hline Healthy & 184 & $53.1 \pm 1.5^{\mathrm{b}}$ & $90.1 \pm 6.7^{\mathrm{b}}$ & $42,4 \%^{\mathrm{a}}$ & $91.3 \%^{\mathrm{a}}$ \\
\hline $\mathrm{RP}$ & 22 & $63.7 \pm 3.3^{\mathrm{a}}$ & $111.0 \pm 15.4^{\mathrm{ab}}$ & $13,7 \%^{\mathrm{b}}$ & $88.4 \%^{\mathrm{a}}$ \\
\hline $\mathrm{CM}$ & 26 & $63.5 \pm 3.7^{\mathrm{a}}$ & $148.8 \pm 16.6^{\mathrm{a}}$ & $18.9 \%^{\mathrm{b}}$ & $49.0 \%^{\mathrm{b}}$ \\
\hline$P$-value & & 0.0013 & 0.0040 & 0.010 & 0.0019 \\
\hline
\end{tabular}

a,b,c Different superscripts within the same column indicate significant differences $(P<0.05) . \mathrm{n}=$ number; $\mathrm{SE}=$ standard error of the mean. RP - Retained placenta; CM - Clinical mastitis postpartum; DO - days 
open; Al - artificial insemination; DPP - days postpartum.

In relation to the calving- 1 st $\mathrm{Al}$ interval and days open, we could reaffirm a better reproductive performance in healthy cows $(P<0.0001$; Figs. 1 and 2$)$. The conception rate at first Al was lower in cows with RP (13.7\%) and CM (18.9\%) groups when compared to the healthy control group (42.4\%; P = 0.01). At 150 days of lactation, $91.3 \%$ of healthy control cows and $88.4 \%$ of RP cows were diagnosed as pregnant; on the other hand, only $49.0 \%$ of cows from CM group were pregnant at 150 days of lactation $(P=0.0019$; Table 2).

\subsection{The influence of RP and CM on endometrial innate immunity and steroidogenic hormone receptors Vital parameters, body condition score and occurrence of subclinical endometritis}

In experiment 2, all cows were apparently healthy according to the clinical examination. Vital parameters and BCS were shown in Table 3. Endometrial cytology was performed on 30 cows from Experiment 2. The Occurrence of subclinical endometritis was $26.6 \%(8 / 30)$. In those positive animals, the occurrence of subclinical endometritis was similar in cows with RP $(40 \% ; P=0.3034)$ and $C M(30 \% ; P=0.582)$ when compared to healthy control cows $(10 \%)$.

Table 3 - Means and standard deviation of the vital parameters evaluated and body condition score of crossbred dairy cows from the three groups in Experiment 2.

\begin{tabular}{lllll} 
& Healthy Control & RP & CM & $P$-value \\
\hline Respiratory Freq. $(\mathrm{mpm})$ & $48.35 \pm 10.78$ & $54.43 \pm 19.59$ & $52.36 \pm 18.81$ & 0.2615 \\
\hline Heart Freq. (bpm) & $68.80 \pm 18.46$ & $71.65 \pm 24.57$ & $71.43 \pm 22.33$ & 0.1121 \\
\hline Ruminal Freq. $(\mathrm{mov} / 3 \mathrm{~min})$ & $2.0 \pm 0.0$ & $2.2 \pm 0.7$ & $2.2 \pm 0.8$ & 0.7443 \\
\hline Temperature $\left({ }^{\circ} \mathrm{C}\right)$ & $38.3 \pm 0.4$ & $38.4 \pm 0.6$ & $38.3 \pm 0.5$ & 0.6044 \\
\hline BCS $(1-5)$ & $2.94 \pm 0.11$ & $2.87 \pm 0.18$ & $3.02 \pm 0.32$ & 0.6517
\end{tabular}

Note: Freq: frequency; mpm: movements/min; bpm: beats per minute; mov/3min: complete ruminal movements in 3 min. One-way ANOVA test with Bonferroni post-test RF, HR and temperature) and Kruskal-Wallis with Dunn's multiple comparison post-test. All tests with a significance of $5 \%(P<0.05)$.

\subsection{Gene expression of interleukins $1 \beta$, IL- 6 and chemokine CCL5 in the bovine endometrium}

The expression of IL-1 $\beta$, IL- 6 and CCL5 were shown in Fig. 3. The expression of IL-1 $\beta$ was higher in groups with RP and CM when compared to the healthy control group $(P<0.05)$. However, no difference was detected in the expression of IL-1 $\beta$ between RP and CM groups. $(P>0.05 ; \mathrm{Fig}$. $3 \mathrm{~A})$. The expression of IL- 6 was lower in cows from the RP group when compared to healthy control and CM groups $(P<0.05$; Fig. 3B). Interestingly, no difference in the expression of the chemokine CCL5 was observed between healthy control, RP and CM groups ( $P>0.05$; Fig. $3 C)$. 


\subsection{Gene expression of estrogen a (ESR1) and progesterone (PGR) receptors in the bovine endometrium}

The expression of both steroid receptors, PGR and ESR1, was not affected by the presence or absence of $\mathrm{RP}$ and $\mathrm{CM}$ evaluated in this study $(\mathrm{P}>0.05$, Figs. $4 \mathrm{~A}, 4 \mathrm{~B})$.

\section{Discussion}

The authors in this experiment tested the hypotheses related to subfertility or infertility in crossbreed dairy cows that developed inflammatory diseases such as RP and CM during the postpartum period and, mainly, their effect on the immune response. Inflammatory diseases have a significant influence on the reproductive efficiency of dairy cows, and their long-term effects, especially on the endometrium, that will be reflected in the reproductive performance (Carvalho et al., 2019; Horlock et al., 2020; Ribeiro et al., 2013; Ribeiro and Carvalho, 2017).

According to Dohmen et al. (2000) and Hammon et al. (2006), the importance of exploring the effects of $\mathrm{RP}$ is that it inhibits uterine defense mechanisms and consequently supports the establishment of infections. In this study, the occurrence of RP in crossbred dairy cows was $9.48 \%$. In a research reported by Buso et al. (2018), they found an incidence of RP around 14.5\%, while Nobre et al. (2012) 12.8\%; both experiments with crossbred Holstein cows.

Another inflammatory disease that was explored in this study was $\mathrm{CM}$. We evaluated its presence until the end of the voluntary waiting period (30 DPP). The occurrence of CM in crossbred dairy cows in this study was $11.2 \%$, similarly, Ribeiro et al. (2013), found an incidence of $12.9 \%$ in crossbred dairy cows and in pure Holstein cows 10.6\% (Ribeiro et al., 2016). According to Van den Borne et al. (2010) and Hammer et al. (2012), during the first 30 days in milk, the incidence of CM was estimated to be 4.6- and 2.0-fold higher than during the remaining lactation in multiparous and primiparous cows, respectively.

Dahl et al. (2017) highlighted the importance of focusing on postpartum CM as it presents solid evidence that it could be a predisposing factor for pregnancy loss, especially in those cows that were confirmed pregnant and later exhibited visual signs of abortion or diagnosed not pregnant. Risco et al. (1999) reported that cows affected with $\mathrm{CM}$ during the first 45 days of pregnancy had a 2.7-fold higher chance of pregnancy loss compared to those cows without CM.

In this research, it was demonstrated that animals with RP and CM had less chances of become pregnant at first Al which demonstrates the negative effect of these inflammatory diseases on the reproductive efficiency of crossbred dairy cows. Also, cows from RP and CM groups had longer calving-to-1 st AI interval and days open compared to healthy control cows.

Other studies also revealed the negative effect of RP and CM on reproductive efficiency. Buso et al. (2018) reported that crossbred dairy cows with RP had longer days open: 46 more days compared to healthy cows. Campos et al. (2020), Dahl et al. (2017), Hudson et al. (2012) and Remnant et al. (2019), showed that cows with $\mathrm{CM}$ needed to be re-inseminated by $20 \%$ more time when mastitis occurred before 
the first Al, reducing Al numbers per conception from $50-20 \%$ and increasing days open from 84 up to 160 days.

After some reproductive parameters were explored, we wanted to understand the link between the presence of inflammatory diseases and the innate immune system. We studied the influence of RP and $\mathrm{CM}$, especially on the innate endometrial immune response by evaluating subclinical endometritis, immune inflammatory cytokines and steroidogenic hormone receptor gene expression in the endometrium. According to Campos et al. (2018), the presence of CM in dairy cows causes important changes in endometrial gene expression, including those involved in the immune response, in cell adhesion molecules and in signaling pathways. In animals with subclinical mastitis, alterations in the expression of theca and granular cells is also observed (Lavon et al., 2011).

In this study, the occurrence of subclinical endometritis was $26.7 \%$; which was notably higher in cows with RP and CM ( $40 \%$ and $30 \%$, respectively) when compared to healthy control cows (10\%). In a study conduct by Carneiro et al. (2014) they found an incidence of subclinical endometritis in crossbred dairy cows of $26 \%$, however the presence of subclinical endometritis in the dairy herd did not affect the conception rate at first $\mathrm{Al}$ and the pregnancy rate at $150 \mathrm{DPP}$.

An increase in the proportion of PMN cells (especially neutrophils) is a prognostic for impaired subsequent reproductive performance (Barlund et al., 2008; Gilbert et al., 2005; Kasimanickam et al., 2004).

Kimura et al. (2002) found that neutrophils from cows that developed RP showed significantly lower function than those from cows without RP before calving and during the first two weeks postpartum. Also, a strong prepartum immune response was suggested to be important for RP prevention. Furthermore, a decrease in the animal's immune response increased the incidence of RP.

An appropriate regulation of immune responses after calving is important for subsequent uterine health (LeBlanc et al., 2011; Zerbe et al., 2000). Uterine infections developed immediately postpartum activate and transport innate immune cells (mainly neutrophils) into the uterus as a result of local cytokine actions (Dadarwal et al., 2017; Sheldon et al., 2009, 2006). Inflammatory molecules such as cytokines and chemokines are released from a variety of cell types; they work as immune messengers to recruit neutrophils and macrophages to the uterine stroma and the lumen and promote phagocytosis of bacteria and cellular debris (Carneiro et al., 2016; LeBlanc, 2014; Sheldon et al., 2008).

In this experiment we evaluated the gene expression of pro-inflammatory cytokines such as IL-1 $\beta$ and IL-6 and the chemokine CCL5. We demonstrated that inflammatory diseases such as RP and CM affected genes related to the innate endometrial immune system, especially by the production of both cytokines (IL-1 $\beta$ and IL-6), whereas these inflammatory diseases did not affect the release of steroidogenic hormone receptors. 
The expression of IL-1 $\beta$ was higher in the groups with RP and CM in relation to the healthy control group, although no difference in the expression of IL-1 $\beta$ between RP and CM groups was detected. This finding corroborates with the results presented by Fischer et al. (2010), they observed that IL-1 $\beta$ was less expressed in healthy control cows when compared to those with clinical or subclinical endometritis. In the present study the expression of IL-1 $\beta$ was evaluated at 45 DPP, unlike Fischer et al.(2010) who evaluated it early in the puerperium (21-27 DPP), demonstrating that the effects on the expression of IL-1 $\beta$ may extend for longer after the disease.

Shaheen et al. (2020) found an increase in the levels of TNF- $\alpha$ and IL-1 $\beta$ in crossbred dairy cows with subclinical and clinical mastitis, suggesting their role in the early stage of the development of mastitis. IL$1 \beta$ is an important cytokine, as it activates vascular endothelial cells and has the capacity to promote the infiltration of inflammatory cells (Dinarello, 2002) and stimulate the release of acute-phase proteins such as haptoglobin, serum amyloid A protein, ceruloplasmin and C-reactive protein by the liver (Heinrich et al., 1990).

In this research, the expression of IL-6 was lower in cows from RP group compared to the healthy control and CM groups. Similarly, Singh et al. (2008) found high levels of this cytokine associated with bovine endometritis, and low levels with RP. Ishikawa et al. (2004) evaluated Holstein cows around two months before and after calving and observed that those cows with RP had lower IL-6 blood concentrations than those without RP; they believed that the reduction in IL-6 before parturition could be a tool to predict progesterone receptors after parturition. In contrast, Shaheen et al. (2020) observed an increase in the levels of cytokines as IL-2 and IL-6 in lactating crossbreed cows diagnosed with CM.

Interestingly, no difference in the expression of chemokine CCL5 was observed between healthy, RP and CM groups. Fagundes et al. (2019) found no differences in the expressions of CCL5 in cows when caruncular and intercaruncular regions of the endometrial epithelium were compared in cases of absent or mild inflammation; however, the expression was higher in endometrium with severe inflammation when compared to groups with mild inflammation or none.

In this study, we aimed to find a relationship between the expression of steroidogenic genes and postpartum immune function. According to Boos et al. (2006) the bovine intercaruncular uterine wall expresses progesterone receptors (PRs), estrogen receptors (ERs) and glucocorticoid receptors (GRs) in cell-type-specific, location-specific and pregnancy stage-specific patterns. Schäubli et al. (2008) indicated that steroidogenic receptors are expressed in the bovine intercaruncular uterine wall during late pregnancy and around parturition and exhibit cell-type-specific distribution patterns.

Little is known about the effect of intrauterine and extra-uterine disease on the gene expression of ESR1 and PGR steroid receptors, and in this study, there was no interference of the disease (RP or CM) in the expression of these receptors in crossbred dairy cows, probably because endometrial samples were collected at the end of the puerperium when immune resolution had already started. 
The results found in the present study exhibited that crossbred dairy cows with uterine or extra-uterine diseases have their reproductive performance affected. In addition, persistent changes in the endometrial environment assessed at the end of the puerperium were observed, suggesting that this may be one of the factors that contribute negatively to the reproductive efficiency of these animals. The effect of postpartum inflammatory diseases (RP and $\mathrm{CM}$ ) on the cows' endometrium immunity were especially detected by IL-1 $\beta$ gene expression, however, it could be stated that for a better understanding of these events a greater number of inflammatory mediators and receptors should be evaluated. Given this information, it would be possible to propose new therapies and preventions to optimize the reproductive and fertility rates of dairy cows. Also, carrying out more studies in this field will help to better understand how long after postpartum this negative effect remains in the uterine environment.

In summary, crossbreed dairy cows with RP and CM had their reproductive efficiency negatively affected and had they initial pro-inflammatory response improved by the increase of IL-1 $\beta$. On the other hand, the low expression of IL- 6 especially in animals with RP may be due by the fact that this cytokine was evaluated later in the postpartum period, as IL- 6 is considered to be an early indicator of inflammatory disease. The gene expression of CCL5 and ESR1 and PGR receptors was not altered by the presence of puerperal diseases as RP and CM.

\section{Declarations}

\section{Acknowledgments}

The authors thank the dairy farms and their employees for allowing their animals for this study, the Nanobiotechnology Laboratory (NANOBIO), Tumors Osteoimmunology and Immunology Laboratory and Animal Biotechnology Laboratory (LABIO) of the Federal University of Uberlândia (UFU); the Fundação de Amparo à Pesquisa de Minas Gerais (FAPEMIG) (Universal Demand - 01/2016 process CVZ - APQ01199-16 - RM Santos); and the Coordenação de Aperfeiçoamento de Pessoal de Nível Superior (CAPES) for the scholarship granted (OP Ramos) and the Conselho Nacional de Desenvolvimento Científico e Tecnológico (CNPq) for the productivity scholarship (JPE Saut). This work was carried out with the support of the CAPES - Financing Code 001.

\section{Funding}

This study was supported by Coordenação de Aperfeiçoamento de Pessoal de Nível Superior (CAPES)Financing Code 001, and Fundação de Amparo à Pesquisa de Minas Gerais - FAPEMIG (APQ-01199-16 RM Santos)

\section{Conflict of Interest Statement}

The authors declare that they have no conflict of interest.

\section{Ethics approval}


All procedures in this study were conducted according to the Ethical Principles in Animal Experimentation approved by the Committee of Ethics in the Use of Animals (CEUA) of the Federal University of Uberlândia, under the protocol 003/17.

\section{Consent for publication}

Not applicable.

\section{Availability of data and material}

Not applicable.

\section{Code availability}

Not applicable.

\section{Authors' contributions}

Oglênia Pereira Ramos: Investigation, Methodology, Writing - original draft. Amanda Lima Rezende: Investigation, Methodology. Paula Batista de Alvarenga: Investigation, Methodology. Carla Cristian Campos: Investigation, Methodology. Estevão Vieira de Rezende: Investigation, Methodology. Marcelo José Barbosa Silva: Methodology. Luisa Cunha Carneiro: Writing - review and editing. Giovanna Faria de Moraes: Writing - review and editing João Paulo Saut: Conceptualization, Funding acquisition, Project administration, Writing - review and editing. Ricarda Maria dos Santos: Investigation, Methodology, Writing - review and editing.

\section{References}

1. Barlund, C.S., Carruthers, T.D., Waldner, C.L., Palmer, C.W., 2008. A comparison of diagnostic techniques for postpartum endometritis in dairy cattle. Theriogenology 69, 714-723. https://doi.org/10.1016/j.theriogenology.2007.12.005

2. Boos, A., Kohtes, J., Janssen, V., Mülling, C., Stelljes, A., Zerbe, H., Hässig, M., Thole, H.H., 2006. Pregnancy effects on distribution of progesterone receptors, oestrogen receptor a, glucocorticoid receptors, Ki-67 antigen and apoptosis in the bovine interplacentomal uterine wall and foetal membranes. Anim. Reprod. Sci. 91, 55-76. https://doi.org/10.1016/j.anireprosci.2005.03.012

3. Bromfield, J.J., Santos, J.E.P., Block, J., Williams, R.S., Sheldon, I.M., 2015. PHYSIOLOGY AND ENDOCRINOLOGY SYMPOSIUM: Uterine infection: Linking infection and innate immunity with infertility in the high-producing dairy cow1,2. J. Anim. Sci. 93, 2021-2033. https://doi.org/10.2527/jas.2014-8496

4. Buckley, F., Heins, B.J., 2014. Crossbreeding: implications for dairy cow fertility and survival. Anim. Int. J. Anim. Biosci. 8, 122-133. https://doi.org/10.1017/S1751731114000901 
5. Buso, R.R., Campos, C.C., Santos, T.R., Saut, J.P.E., Santos, R.M., 2018. Retenção de placenta e endometrite subclínica: prevalência e relação com o desempenho reprodutivo de vacas leiteiras mestiças. Pesqui. Veterinária Bras. 38, 1-5. https://doi.org/10.1590/1678-5150-pvb-4707

6. Campos, C.C., do Prado, F.L., dos Reis, J.P.J., Carneiro, L.C., Silva, P.R.B., de Moraes, G.F., dos Santos, R.M., 2020. Effects of clinical mastitis and puerperal diseases on reproductive efficiency of dairy cows. Trop. Anim. Health Prod. https://doi.org/10.1007/s11250-020-02326-2

7. Campos, C.C., Hartling, I., Kaur, M., Fernandes, A.C.C., Santos, R.M., Cerri, R.L.A., 2018. Intramammary infusion of lipopolysaccharide promotes inflammation and alters endometrial gene expression in lactating Holstein cows. J. Dairy Sci. 101, 10440-10455. https://doi.org/10.3168/jds.2018-14393

8. Carneiro, L.C., Cronin, J.G., Sheldon, I.M., 2016. Mechanisms linking bacterial infections of the bovine endometrium to disease and infertility. Reprod. Biol. 16.

https://doi.org/10.1016/j.repbio.2015.12.002

9. Carneiro, L.C., Ferreira, A.F., Padua, M., Saut, J.P., Ferraudo, A.S., dos Santos, R.M., 2014. Incidence of subclinical endometritis and its effects on reproductive performance of crossbred dairy cows. Trop. Anim. Health Prod. 46, 1435-1439. https://doi.org/10.1007/s11250-014-0661-y

10. Carvalho, M.R., Peñagaricano, F., Santos, J.E.P., DeVries, T.J., McBride, B.W., Ribeiro, E.S., 2019. Longterm effects of postpartum clinical disease on milk production, reproduction, and culling of dairy cows. J. Dairy Sci. 102, 11701-11717. https://doi.org/10.3168/jds.2019-17025

11. Collins, T., Read, M.A., Neish, A.S., Whitley, M.Z., Thanos, D., Maniatis, T., 1995. Transcriptional regulation of endothelial cell adhesion molecules: NF-KB and cytokine-inducible enhancers. FASEB J. 9, 899-909. https://doi.org/10.1096/fasebj.9.10.7542214

12. Dadarwal, D., Palmer, C., Griebel, P., 2017. Mucosal immunity of the postpartum bovine genital tract. Theriogenology 104, 62-71. https://doi.org/10.1016/j.theriogenology.2017.08.010

13. Dahl, M.O., Maunsell, F.P., De Vries, A., Galvao, K.N., Risco, C.A., Hernandez, J.A., 2017. Evidence that mastitis can cause pregnancy loss in dairy cows: A systematic review of observational studies. J. Dairy Sci. 100, 8322-8329. https://doi.org/10.3168/jds.2017-12711

14. Dalanezi, F.M., Joaquim, S.F., Guimarães, F.F., Guerra, S.T., Lopes, B.C., Schmidt, E.M.S., Cerri, R.L.A., Langoni, H., 2020. Influence of pathogens causing clinical mastitis on reproductive variables of dairy cows. J. Dairy Sci. 103, 3648-3655. https://doi.org/10.3168/jds.2019-16841

15. DINARELLO, C.A., 2002. The IL-1 family and inflammatory diseases. Clin Exp Rheumatol . 20, S1S13.

16. Dohmen, M.J.W., Joop, K., Sturk, A., Bols, P.E.J., Lohuis, J.A.C.M., 2000. Relationship between intrauterine bacterial contamination, endotoxin levels and the development of endometritis in postpartum cows with dystocia or retained placenta. Theriogenology 54, 1019-1032.

https://doi.org/10.1016/S0093-691X(00)00410-6

17. Dubuc, J., Duffield, T.F., Leslie, K.E., Walton, J.S., LeBlanc, S.J., 2011. Effects of postpartum uterine diseases on milk production and culling in dairy cows. J. Dairy Sci. 94, 1339-1346. https://doi.org/10.3168/jds.2010-3758 
18. Edmonson, A.J., Lean, I.J., Weaver, L.D., Farver, T., Webster, G., 1989. A Body Condition Scoring Chart for Holstein Dairy Cows. J. Dairy Sci. 72, 68-78. https://doi.org/10.3168/jds.S0022-0302(89)790810

19. Fagundes, N.S., Rezende, A.L., Alvarenga, P.B., Magalhães, L.Q., Santos, R.M., Headley, S.A., Silva, M.J.B., Beletti, M.E., Saut, J.P.E., 2019. Short communication: Proinflammatory gene expression relative to the collection technique of endometrial samples from cows with and without subclinical endometritis. J. Dairy Sci. 102, 5511-5517. https://doi.org/10.3168/jds.2018-15212

20. FERREIRA ADEMIR DE MORAES, 2010. Reprodução da fêmea bovina: fisiologia aplicada e problemas mais comuns (causas e tratamentos).

21. Fischer, C., Drillich, M., Odau, S., Heuwieser, W., Einspanier, R., Gabler, C., 2010. Selected proinflammatory factor transcripts in bovine endometrial epithelial cells are regulated during the oestrous cycle and elevated in case of subclinical or clinical endometritis. Reprod. Fertil. Dev. 22, 818. https://doi.org/10.1071/RD09120

22. Fourichon, C., Seegers, H., Malher, X., 2000. Effect of disease on reproduction in the dairy cow: a meta-analysis. Theriogenology 53, 1729-1759. https://doi.org/10.1016/S0093-691X(00)00311-3

23. Francisco Leydson F. Feitosa, 2008. Semiologia Veterinária - A Arte do Diagnóstico.

24. Gilbert, R.O., Shin, S.T., Guard, C.L., Erb, H.N., Frajblat, M., 2005. Prevalence of endometritis and its effects on reproductive performance of dairy cows. Theriogenology $64,1879-1888$. https://doi.org/10.1016/j.theriogenology.2005.04.022

25. Hammer, J., Morton, J., Kerrisk, K., 2012. Quarter-milking-, quarter-, udder- and lactation-level risk factors and indicators for clinical mastitis during lactation in pasture-fed dairy cows managed in an automatic milking system. Aust. Vet. J. 90, 167-174. https://doi.org/10.1111/j.17510813.2012.00917.x

26. Hammon, D.S., Evjen, I.M., Dhiman, T.R., Goff, J.P., Walters, J.L., 2006. Neutrophil function and energy status in Holstein cows with uterine health disorders. Vet. Immunol. Immunopathol. 113, 21-29. https://doi.org/10.1016/j.vetimm.2006.03.022

27. Heinrich, P.C., Castell, J. V, Andus, T., 1990. Interleukin-6 and the acute phase response. Biochem. J. 265, 621-636. https://doi.org/10.1042/bj2650621

28. Horlock, A.D., Piersanti, R.L., Ramirez-Hernandez, R., Yu, F., Ma, Z., Jeong, K.C., Clift, M.J.D., Block, J., Santos, J.E.P., Bromfield, J.J., Sheldon, I.M., 2020. Uterine infection alters the transcriptome of the bovine reproductive tract three months later. Reproduction 160, 93-107. https://doi.org/10.1530/REP-19-0564

29. Huber, A., Kunkel, S., Todd, R., Weiss, S., 1991. Regulation of transendothelial neutrophil migration by endogenous interleukin-8. Science (80-. ). 254, 99-102. https://doi.org/10.1126/science.1718038

30. Hudson, C.D., Bradley, A.J., Breen, J.E., Green, M.J., 2012. Associations between udder health and reproductive performance in United Kingdom dairy cows. J. Dairy Sci. 95, 3683-3697. https://doi.org/10.3168/jds.2011-4629 
31. Huszenicza, G., Janosi, S., Kulcsar, M., Korodi, P., Reiczigel, J., Katai, L., Peters, A., De Rensis, F., 2005. Effects of Clinical Mastitis on Ovarian Function in Post-partum Dairy Cows. Reprod. Domest. Anim. 40, 199-204. https://doi.org/10.1111/j.1439-0531.2005.00571.x

32. ISHIKAWA, Y., NAKADA, K., HAGIWARA, K., KIRISAWA, R., IWAI, H., MORIYOSHI, M., SAWAMUKAI, Y., 2004. Changes in Interleukin-6 Concentration in Peripheral Blood of Pre- and Post-Partum Dairy Cattle and Its Relationship to Postpartum Reproductive Diseases. J. Vet. Med. Sci. 66, 1403-1408. https://doi.org/10.1292/jvms.66.1403

33. Islam, MH, Sarder, M., Rahman, M., Kader, M., Islam, MA, 2012. Incidence of Retained Placenta in Relation with Breed, Age, Parity and Body Condition Score of Dairy cows. Int. J. Nat. Sci. 2, 15-20. https://doi.org/10.3329/ijns.v2i1.10878

34. JOOSTEN, I., SANDERS, M.F., HENSEN, E.J., 2009. Involvement of major histocompatibility complex class I compatibility between dam and calf in the aetiology of bovine retained placenta. Anim. Genet. 22, 455-463. https://doi.org/10.1111/j.1365-2052.1991.tb00717.x

35. Karsch, F.J., Battaglia, D.F., Breen, K.M., Debus, N., Harris, T.G., 2002. Mechanisms for Ovarian Cycle Disruption by Immune/inflammatory Stress. Stress 5, 101-112. https://doi.org/10.1080/10253890290027868

36. Kasimanickam, R., Duffield, T.., Foster, R.., Gartley, C.., Leslie, K.., Walton, J.., Johnson, W.., 2004. Endometrial cytology and ultrasonography for the detection of subclinical endometritis in postpartum dairy cows. Theriogenology $62,9-23$. https://doi.org/10.1016/j.theriogenology.2003.03.001

37. Kimura, K., Goff, J.P., Kehrli, M.E., Reinhardt, T.A., 2002. Decreased Neutrophil Function as a Cause of Retained Placenta in Dairy Cattle. J. Dairy Sci. 85, 544-550. https://doi.org/10.3168/jds.S00220302(02)74107-6

38. Koh, A., da Silva, A.P.B., Bansal, A.K., Bansal, M., Sun, C., Lee, H., Glogauer, M., Sodek, J., Zohar, R., 2007. Role of osteopontin in neutrophil function. Immunology 122, 466-475. https://doi.org/10.1111/j.1365-2567.2007.02682.x

39. Lavon, Y., Leitner, G., Klipper, E., Moallem, U., Meidan, R., Wolfenson, D., 2011. Subclinical, chronic intramammary infection lowers steroid concentrations and gene expression in bovine preovulatory follicles. Domest. Anim. Endocrinol. 40, 98-109. https://doi.org/10.1016/j.domaniend.2010.09.004

40. LeBlanc, S.J., 2014. Reproductive tract inflammatory disease in postpartum dairy cows. animal 8 , 54-63. https://doi.org/10.1017/S1751731114000524

41. LeBlanc, S.J., 2008. Postpartum uterine disease and dairy herd reproductive performance: A review. Vet. J. 176, 102-114. https://doi.org/10.1016/j.tvjl.2007.12.019

42. LeBlanc, S.J., Osawa, T., Dubuc, J., 2011. Reproductive tract defense and disease in postpartum dairy cows. Theriogenology 76, 1610-1618. https://doi.org/10.1016/j.theriogenology.2011.07.017

43. McDougall, S., Macaulay, R., Compton, C., 2007. Association between endometritis diagnosis using a novel intravaginal device and reproductive performance in dairy cattle. Anim. Reprod. Sci. 99, 9-23. https://doi.org/10.1016/j.anireprosci.2006.03.017 
44. Nobre, M.M., Coelho, S.G., Haddad, J.P.A., Campos, E.F., Lana, A.M.Q., Reis, R.B., Saturnino, H.M., 2012. Avaliação da incidência e fatores de risco da retenção de placenta em vacas mestiças leiteiras. Arq. Bras. Med. Veterinária e Zootec. 64, 101-107. https://doi.org/10.1590/S010209352012000100015

45. Remnant, J., Green, M.J., Huxley, J., Hirst-Beecham, J., Jones, R., Roberts, G., Hudson, C.D., 2019. Association of lameness and mastitis with return-to-service oestrus detection in the dairy cow. Vet. Rec. 185, 442-442. https://doi.org/10.1136/vr.105535

46. Ribeiro, E.S., Carvalho, M.R., 2017. Impact and mechanisms of inflammatory diseases on embryonic development and fertility in cattle. Anim. Reprod. 14, 589-600. https://doi.org/10.21451/1984-3143AR1002

47. Ribeiro, E.S., Gomes, G., Greco, L.F., Cerri, R.L.A., Vieira-Neto, A., Monteiro, P.L.J., Lima, F.S., Bisinotto, R.S., Thatcher, W.W., Santos, J.E.P., 2016. Carryover effect of postpartum inflammatory diseases on developmental biology and fertility in lactating dairy cows. J. Dairy Sci. 99, 2201-2220. https://doi.org/10.3168/jds.2015-10337

48. Ribeiro, E.S., Lima, F.S., Greco, L.F., Bisinotto, R.S., Monteiro, A.P.A., Favoreto, M., Ayres, H., Marsola, R.S., Martinez, N., Thatcher, W.W., Santos, J.E.P., 2013. Prevalence of periparturient diseases and effects on fertility of seasonally calving grazing dairy cows supplemented with concentrates. J. Dairy Sci. 96, 5682-5697. https://doi.org/10.3168/jds.2012-6335

49. Risco, C.A., Donovan, G.A., Hernandez, J., 1999. Clinical Mastitis Associated with Abortion in Dairy Cows. J. Dairy Sci. 82, 1684-1689. https://doi.org/10.3168/jds.S0022-0302(99)75397-X

50. Roberson, J.R., 2012. Treatment of Clinical Mastitis. Vet. Clin. North Am. Food Anim. Pract. 28, 271288. https://doi.org/10.1016/j.cvfa.2012.03.011

51. Schäubli, M., Ritter, N., Hässig, M., Zerbe, H., Bleul, U., Boos, A., 2008. Progesterone receptors, oestrogen receptor $a$ and glucocorticoid receptors in the bovine intercaruncular uterine wall around parturition. Anim. Reprod. Sci. 103, 215-227. https://doi.org/10.1016/j.anireprosci.2006.12.015

52. Shaheen, T., Bilal Ahmad, S., Rehman, M.U., Muzamil, S., Razak Bhat, R., Hussain, I., Bashir, N., Mir, M.U.R., Paray, B.A., Dawood, M.A.O., 2020. Investigations on cytokines and proteins in lactating cows with and without naturally occurring mastitis. J. King Saud Univ. - Sci. 32, 2863-2867. https://doi.org/10.1016/j.jksus.2020.07.009

53. Sheldon, I.M., 2019. The Metritis Complex in Cattle, in: Veterinary Reproduction and Obstetrics. Elsevier, pp. 408-433. https://doi.org/10.1016/B978-0-7020-7233-8.00023-9

54. Sheldon, I.M., Cronin, J., Goetze, L., Donofrio, G., Schuberth, H.-J., 2009. Defining Postpartum Uterine Disease and the Mechanisms of Infection and Immunity in the Female Reproductive Tract in Cattle1. Biol. Reprod. 81, 1025-1032. https://doi.org/10.1095/biolreprod.109.077370

55. Sheldon, I.M., Cronin, J.G., Bromfield, J.J., 2019. Tolerance and Innate Immunity Shape the Development of Postpartum Uterine Disease and the Impact of Endometritis in Dairy Cattle. Annu. Rev. Anim. Biosci. 7, 361-384. https://doi.org/10.1146/annurev-animal-020518-115227 
56. Sheldon, I.M., Lewis, G.S., LeBlanc, S., Gilbert, R.O., 2006. Defining postpartum uterine disease in cattle. Theriogenology 65, 1516-1530. https://doi.org/10.1016/j.theriogenology.2005.08.021

57. Sheldon, I.M., Owens, S.E., 2017. Postpartum uterine infection and endometritis in dairy cattle. Anim. Reprod. 14, 622-629. https://doi.org/10.21451/1984-3143-AR1006

58. Sheldon, I.M., Rycroft, A.N., Zhou, C., 2004. Association between postpartum pyrexia and uterine bacterial infection in dairy cattle. Vet. Rec. 154, 289-293. https://doi.org/10.1136/vr.154.10.289

59. Sheldon, I.M., Williams, E.J., Miller, A.N.A., Nash, D.M., Herath, S., 2008. Uterine diseases in cattle after parturition. Vet. J. 176, 115-121. https://doi.org/10.1016/j.tvjl.2007.12.031

60. Singh, J., Murray, R.D., Mshelia, G., Woldehiwet, Z., 2008. The immune status of the bovine uterus during the peripartum period. Vet. J. 175, 301-309. https://doi.org/10.1016/j.tvjl.2007.02.003

61. Stangaferro, M.L., Wijma, R.W., Giordano, J.O., 2019. Profitability of dairy cows submitted to the first service with the Presynch-Ovsynch or Double-Ovsynch protocol and different duration of the voluntary waiting period. J. Dairy Sci. 102, 4546-4562. https://doi.org/10.3168/jds.2018-15567

62. van den Borne, B.H.P., van Schaik, G., Lam, T.J.G.M., Nielen, M., 2010. Variation in herd level mastitis indicators between primi- and multiparae in Dutch dairy herds. Prev. Vet. Med. 96, 49-55. https://doi.org/10.1016/j.prevetmed.2010.05.010

63. Wathes, D.C., Cheng, Z., Chowdhury, W., Fenwick, M.A., Fitzpatrick, R., Morris, D.G., Patton, J., Murphy, J.J., 2009. Negative energy balance alters global gene expression and immune responses in the uterus of postpartum dairy cows. Physiol. Genomics 39, 1-13.

https://doi.org/10.1152/physiolgenomics.00064.2009

64. Zerbe, H., Schneider, N., Leibold, W., Wensing, T., Kruip, T.A.M., Schuberth, H.J., 2000. Altered functional and immunophenotypical properties of neutrophilic granulocytes in postpartum cows associated with fatty liver. Theriogenology 54, 771-786. https://doi.org/10.1016/S0093$691 \times(00) 00389-7$

\section{Figures}




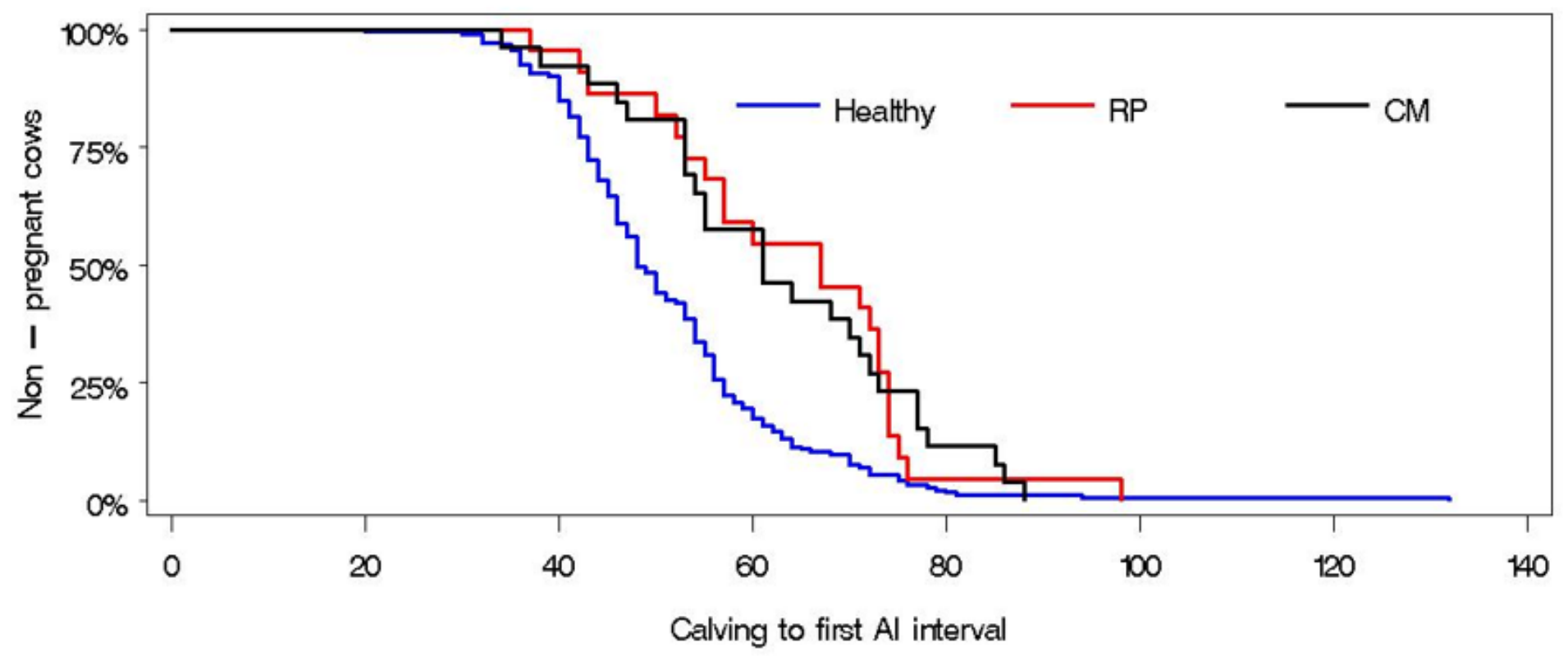

Figure 1

Survival curves for non-pregnant cows (\%) related to calving to first artificial insemination (Al) interval according to the groups healthy (blue line), retained placenta (RP; red line) or clinical mastitis postpartum $(\mathrm{CM}$; black line $)$ in lactating dairy cows $(\mathrm{P}<0.0001)$.

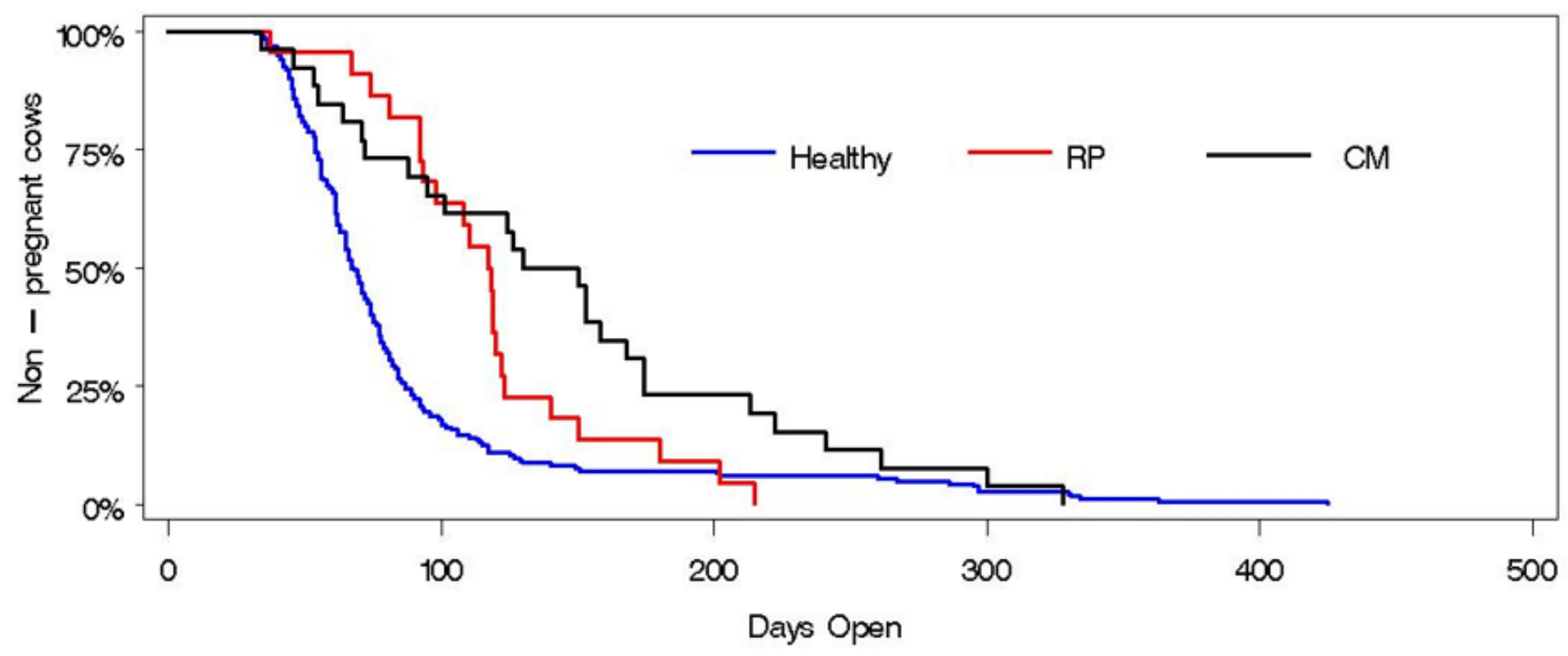

Figure 2

Survival curves for non-pregnant cows (\%) related to days open according to the groups healthy (blue line), retained placenta (RP; red line) or clinical mastitis postpartum (CM; black line) in lactating dairy cows $(P<0.0001)$. 

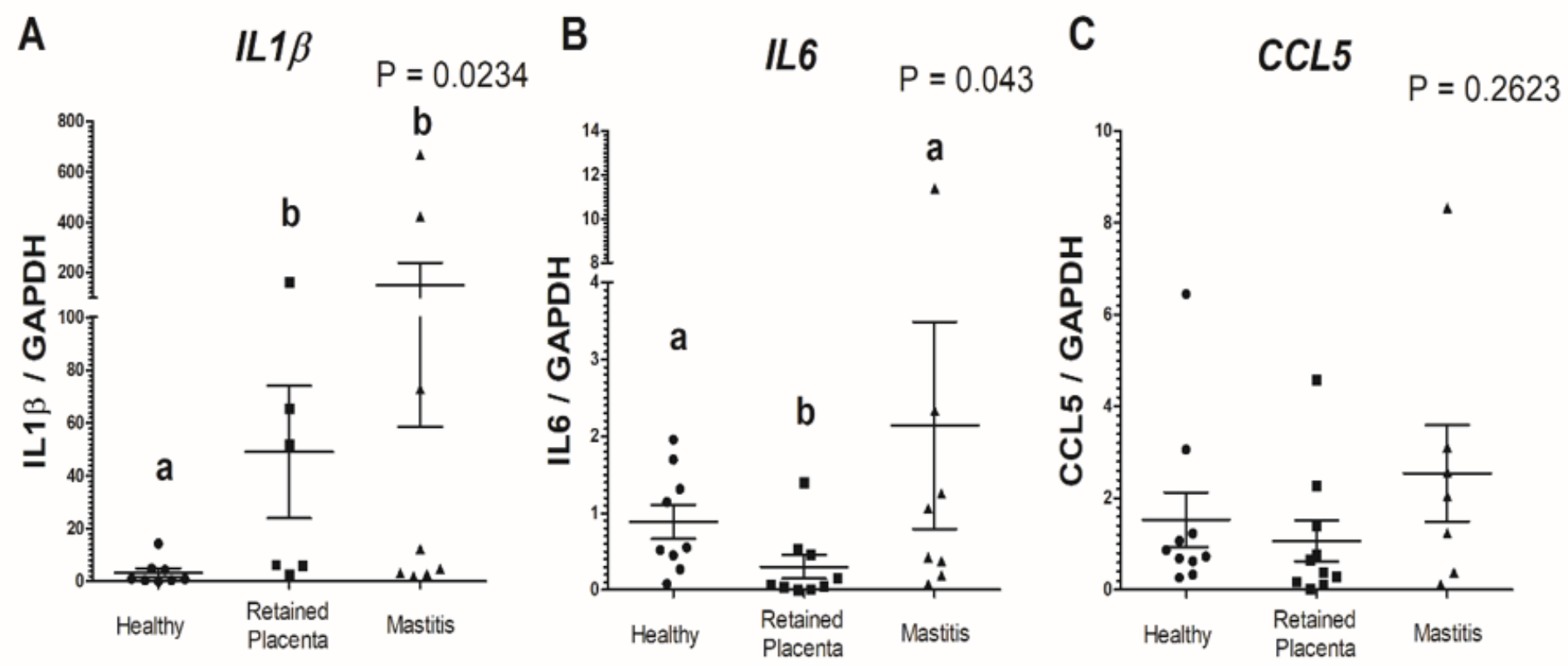

\section{Figure 3}

Expression of IL-1 $\beta$, IL-6 and CCL5 genes of crossbred dairy cows. Different letters indicate statistical difference by one-way ANOVA and Bonferroni's multiple comparison post-test $(P<0.05)$.

A

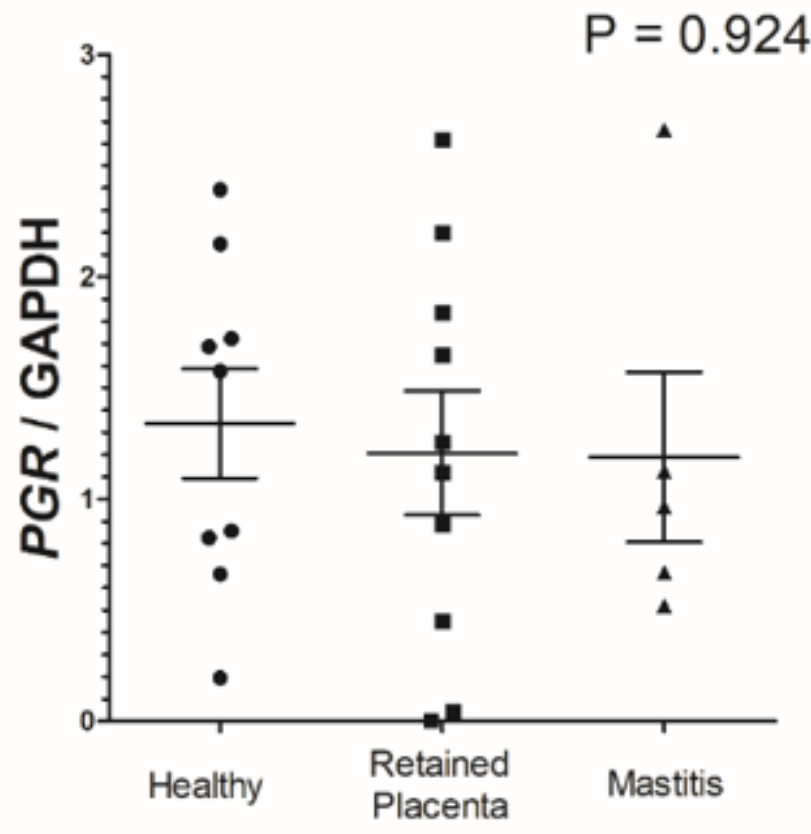

B

ESR1

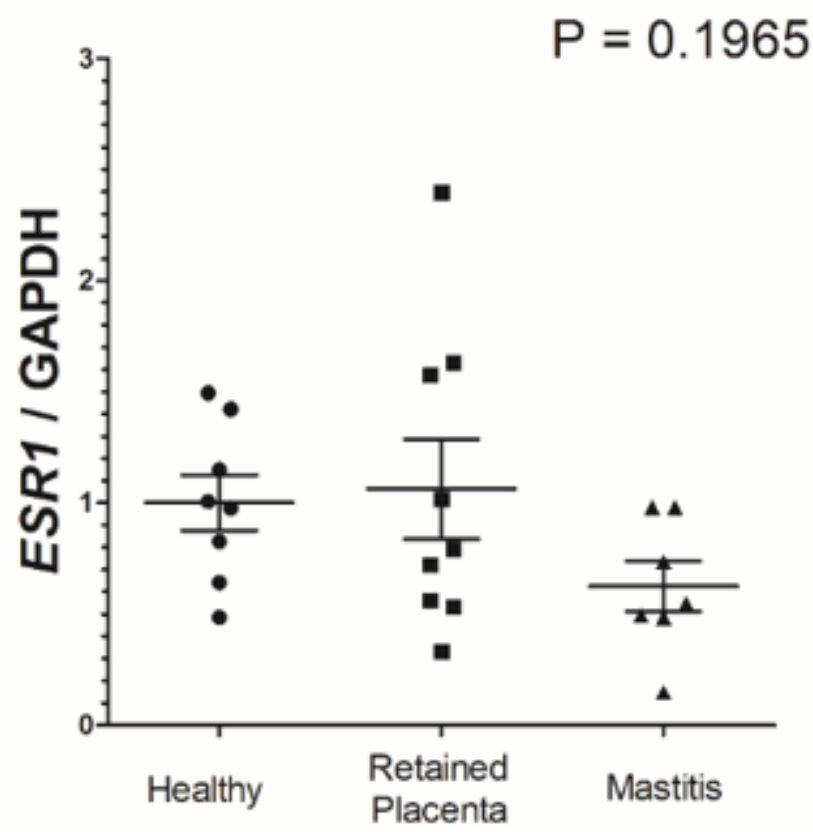

Figure 4

Expression of steroid receptors in crossbred dairy cows. Different letters indicate statistical difference by one-way ANOVA with the Bonferroni multiple comparison post-test at $5 \%$ significance level $(P<0.05)$. 